\title{
Effect of Poultry Manure, Defatted Palm Kernel Cake and Their Combinations on the Yield Performance of Sweet Potato (Ipomoea batatas (L.) Lam) and Chemical Characteristics of a Sandy Loam Ultisol of South-Eastern Nigerian
}

\author{
I. K. Okore ${ }^{1,3}$, B. C. N. Okonkwo ${ }^{2,3} \&$ K. S. Osuaku ${ }^{3}$ \\ ${ }^{1}$ Rubber Research Institute of Nigeria, PMB 1049, Benin, Edo State (Akwete Sub Station), Nigeria \\ ${ }^{2}$ National Root Crop Research Institute of Nigeria, Umudike, Abia State, Nigeria \\ ${ }^{3}$ Department of Soil Science \& Environmental Management, Imo State University, Owerri, Nigeria \\ Correspondence: I. K. Okore, Rubber Research Institute of Nigeria, PMB 1049, Benin, Edo State, Nigeria. Tel: \\ 234-803-572-8268. E-mail: iko7796@yahoo.co.uk
}

Received: August 31, 2015

Accepted: September 18, 2015 Online Published: October 15, 2015

doi:10.5539/jas.v7n11p260

URL: http://dx.doi.org/10.5539/jas.v7n11p260

\begin{abstract}
A two- year (2010 and 2011 cropping seasons) field trial was carried out on a Sandy loam Ultisol in south-eastern Nigeria to evaluate the effect of Poultry manure (PM), Defatted palm kernel cake (DPKC) and their combinations $(\mathrm{PM}+\mathrm{DPKC})$ on the yield of sweet potato and soil chemical properties. The experiment was laid-out in a randomised complete block design with the treatments consisting of PM, DPKC, PM + DPKC (1:1 by weight) applied at the rates of 5 and $10 \mathrm{t} \mathrm{ha}^{-1}$ each and a control (no soil amendment). The treatments were replicated four times. A significantly $(\mathrm{P} \leq 0.05)$ higher sweet potato yield performances and improved soil chemical characteristics were recorded from plots that received any of the soil amendments compared to the unamended (control plots). Apart from the combined application of PM and DPKC at the rate of $5 \mathrm{t} \mathrm{ha}^{-1}$ which gave a significantly higher yield values relative to single application of either PM or DPKC at similar rate; the effect of the other treatments at the same rate of application on the crop yield and yield related parameters did not differ significantly. However, plots that had either DPKC alone or in combination with PM gave a significantly higher root:vine yield ratio and commercial harvest index, irrespective of the rate of application. Similarly, combined application of PM and DPKC resulted in a significantly higher soil org. C, available P and exchangeable bases. The crop yield values and soil properties recorded from plots treated with PM + DPKC at the rates of 5 and $10 \mathrm{t}$ $\mathrm{ha}^{-1}$ did not differ significantly, hence combined application of PM and DPKC at the rate of $5 \mathrm{tha}^{-1}$ could be considered suitable for sweet potato yield and soil nutrient conservation for sandy loam ultisol of south-eastern Nigeria.
\end{abstract}

Keywords: defatted palm kernel cake, sweet potato, root:vine yield ratio, soil nutrient

\section{Introduction}

Sweet potato (Ipomoea batatas (L.) Lam) is among the major energy food source for man and livestock and as well has a high industrial value. The crop is adopted to wide range of soil texture, with sandy loam being the most suitable (Jacoby, 1965; Titus, 2008).In Nigeria, sweet potato cultivation has gained a wide acceptance in the humid areas (Akoroda, 2009). Predominantly, the soil texture in the area ranges from sandy loam to sandy clay loam (Agboola, 1979). However such soil tend to have very low nutrient retention potentials (Ekpete, 1972; Maduakor, 1991) and are highly prone to nutrient loss, especially the base cations, such as potassium $\left(\mathrm{K}^{+}\right)$.

High sweet potato tuber yield and quality (starch content) maintenance requires high amount of $\mathrm{K}$ relative to other macro nutrients like N or P (Jacoby, 1965; Jian-weil et al., 2001). Norman et al. (1984) reported on the effect of $\mathrm{N}$ and $\mathrm{K}$ nutrient ratios in fertilizer on the tuber:vine yield ratio of sweet potato, with wider $\mathrm{N}: \mathrm{K}$ nutrient ratios resulting in narrow tuber: vine yield ratios. A study by Jian-weil et al. (2001) revealed that higher applications of $\mathrm{N}$ and $\mathrm{P}$ to sweet potato plots relative to $\mathrm{K}$ resulted in $\mathrm{K}, \mathrm{N}$ and $\mathrm{P}$ imbalance and a significant drop in tuber quality and yield. These reports are of considerable importance in determining a suitable organic fertilizer for the crop when grown in soils of low K content such as those of south-eastern Nigeria and the major 
nutrients in most organic fertilizers are $\mathrm{N}$ and $\mathrm{P}$.

The use of poultry manure (PM) or poultry litter (PL) as soil amendment for crop production has long gained a general acceptance compared to other animal manure. This has mainly been attributed to its relative high available $\mathrm{N}$ and $\mathrm{P}$ content and their quick release for plant use (Hue \& Silver, 1995). However, in recent years the unavailability of PM or PL resulting from their wide spread utilization as manure and fewer number of poultry farmers in the rural parts of south eastern Nigeria has made the affordability prohibitive to the resource poor farmers. This has necessitated the sourcing and utilization of other easily available and affordable organic waste that has close nutrient characteristics to PM.

Some defatted seed cakes have been recommended by Africa Organic Agriculture Research Institute - FIBL (2011) as a suitable organic fertilizer for commercial organic farming. Studies (Okore et al., 2007; Okore \& Akpobome, 2011; Ogbonna et al., 2012) across different locations in southern Nigeria have shown the positive effects of the defatted rubber seed, palm kernel and shear butter seed cakes not only on crop yield and quality, but also on soil nutrient as well, especially when mixed with mineral fertilizers. With the high $\mathrm{K}$ content of defatted palm kernel cake (Okore et al., 2007) and the N richness of PM (Hue \& Silver, 1995); the objective of this study is to evaluate their effect when applied singly or in combination on the yield performances of sweet potato and the chemical properties of a sandy loam ultisol of south-eastern Nigeria.

\section{Materials and Methods}

\subsection{Experimental Site}

The study was conducted at the Western Farm of the National Root Crop Research Institute of Nigeria (NRCRIN), Umudike, during the 2010 and 2011 cropping seasons. Umudike lies at Lat. $0.5^{\circ} 29^{\prime} \mathrm{N}$ and Long. $07^{\circ} 38^{\prime} \mathrm{E}$. The area has two major seasons (rainy and dry) yearly, with a mean annual rainfall of $2166 \mathrm{~mm}$. The mean relative humidity during the rainy and dry periods is 84 and $52 \%$ respectively, while the mean daily temperature is $27{ }^{\circ} \mathrm{C}$. Texturally, the soil of experimental site is sandy loam (79\% sand, 5\% silt and 16\% clay) at upper layer $0-35 \mathrm{~cm}$, with acid property (Table 1).

Table 1. Mean Chemical properties of the poultry manure and defatted palm kernel cake used as soil amendment in the study and the pre amended soil

\begin{tabular}{llll}
\hline Chemical properties & Poultry manure & Defatted palm kernel cake & Pre-amended soil $(0-30 \mathrm{~cm}$ depth $)$ \\
\hline $\mathrm{Ca}\left(\% ; \mathrm{Cmol} \mathrm{kg}^{-1}\right)^{*}$ & 6.21 & 4.21 & 1.20 \\
$\mathrm{Mg}\left(\% ; \mathrm{Cmol} \mathrm{kg}^{-1}\right)^{*}$ & 2.31 & 1.49 & 0.80 \\
$\mathrm{~K}\left(\% ; \mathrm{Cmol} \mathrm{kg}^{-1}\right)^{*}$ & 0.48 & 1.80 & 0.10 \\
$\mathrm{Na}\left(\% ; \mathrm{Cmol} \mathrm{kg}^{-1}\right)^{*}$ & 1.98 & 1.74 & 0.09 \\
$\mathrm{P}\left(\% ; \mathrm{mg} \mathrm{kg}^{-1}\right)^{*}$ & 1.85 & 0.65 & 8.72 \\
$\mathrm{~N} \%$ & 1.96 & 0.97 & 0.07 \\
$\mathrm{Org} . \mathrm{C}(\%)$ & 12.68 & 15.24 & 1.05 \\
$\mathrm{pH}\left(\mathrm{H}{ }_{2} \mathrm{O}\right)$ & - & - & 4.62 \\
Exchg. Acidity $\left(\mathrm{Cmol} \mathrm{kg}^{-1}\right)$ & - & - & 0.82 \\
$\mathrm{C}: \mathrm{N}($ ratio $)$ & 6.47 & 15.71 & 17.86 \\
\hline
\end{tabular}

Note. * Unit for the measurement of soil values.

\subsection{Experimental Design}

The experiment was laid out in randomised complete block design (RCBD) with seven treatments. The treatments consisted of two rates $\left(5\right.$ and $\left.10 \mathrm{t} \mathrm{ha}^{-1}\right)$ each of poultry manure - PM, defatted palm kernel cake DPKC and their combinations - PM + DPKC (1:1 by weight) and a check (no treatment application). Each of the treatment was replicated four times. Analysis of the relevant chemical characteristics of the applied PM and DPKC which revealed a comparative higher $\mathrm{N}$ and $\mathrm{K}$, respectively are shown in Table 1 .

The treatments at the various rates were applied in powdery form after being air dried at room temperature and crushed with a hammer mill. They were applied to the soil by incorporation, seven days before planting of the sweet potato (Var. 1587/0087) sourced from NRCRIN, Umudike. Planting of the crop was through vine, with each vine having four nodes. The veins planted were on ridges at the spacing of $30 \mathrm{~cm}$ within and $100 \mathrm{~cm}$ 
between rows, with each experimental unit containing four ridges. Each of the ridge measured $500 \mathrm{~cm}$ long.

\subsection{Data Collection and Analysis}

Prior to their application, the chemical characteristics of the PM and DPKC were determined by analysing them for $\mathrm{N}$ using micro kjeldahl method, $\mathrm{P}, \mathrm{K}, \mathrm{Ca}$ and $\mathrm{Mg}$ using the per chloric acid digestion method (IITA, 1982). The organic Carbon in the materials was determined by combustion method (Chintala et al., 2013).

Yield performance data were taken at each harvest year. A total of 30 sweet potato stands in each treatment plot were harvested from the middle row of the plot and used for the yield parameter determination. The parameters measured include: total weight of marketable tubers (tubers that weighed more than $100 \mathrm{~g}$ ) and unmarketable tubers (tubers that weighed less than $100 \mathrm{~g}$ ), total tuber yield $\left(\mathrm{t} \mathrm{h}^{-1}\right)$, fresh above ground biomass (Vine) yield, harvest and commercial harvest indexes. Harvest index was estimated as the ratio of total storage tuber yield to the total biomass at harvest (sum of storage tuber yield and the vegetative biomass-vine) and commercial harvest index was estimated as the ratio of the weight of the marketable storage tubers to the total storage tuber yield as described by CRI (2003).

Prior to the treatment application and at the end of each crop harvest, composite samples were taken at the depth of 0-30 cm from the experimental and treated plots, respectively. The samples were air dried, crushed and sieved with $2 \mathrm{~mm}$ sieve mesh.

Particle size distribution was determined on the pre-treatment application samples only, with the use of Bouyoucos method. The chemical properties $\left(\mathrm{pH}-\mathrm{H}_{2} \mathrm{O}\right.$, org. $\mathrm{C}$, total $\mathrm{N}$, available P-Bray 1 and exchangeable bases and acidity) of the pre and post treatment application soil samples were determined using the procedure described by Okalebo et al. (1993). The soil $\mathrm{pH}$ in water (a soil/water ratio of 2.5:1 - Weight:Volume) was determined using a $\mathrm{pH}$ meter with glass electrode. Total soil $\mathrm{N}$ was analysed following the kjeldahl analytical procedure which involve digesting the samples with a mixture of $0.42 \mathrm{~g} \mathrm{Se}$ (powder), $14 \mathrm{~g} \mathrm{Li}_{2} \mathrm{SO}_{4} \mathrm{H}_{2} \mathrm{O}, 30 \%$ $\mathrm{H}_{2} \mathrm{O}_{2}$ and $420 \mathrm{ml}$ of conc. $\mathrm{H}_{2} \mathrm{SO}_{4}$, followed by steam distillation in the presence of excess alkaline $(40 \% \mathrm{NaOH})$. Org. $\mathrm{C}$ content of the soil was measured by using $0.5 \mathrm{~N} \mathrm{~K}_{2} \mathrm{Cr}_{2} \mathrm{O}_{7}$ in conc. $\mathrm{H}_{2} \mathrm{SO}_{4}$ and $0.2 \mathrm{~N} \mathrm{Fe}\left(\mathrm{NH}_{4}\right)_{2}\left(\mathrm{SO}_{4}\right)_{2}$ mixture with N-phenylanthranilic indicator. Available $\mathrm{P}$ was extracted with Bray-1 $\left(0.03 \mathrm{~N} \mathrm{NH}_{4} \mathrm{~F}+0.025 \mathrm{~N} \mathrm{HCl}\right)$ and the $\mathrm{P}$ was read from a spectrophotometer. The exchangeable bases $\left(\mathrm{K}^{+}, \mathrm{Na}^{+}, \mathrm{Mg}^{2+}\right.$ and $\left.\mathrm{Ca}^{2+}\right)$ were determined by first extracting with $1 \mathrm{~N} \mathrm{NH}_{4} \mathrm{OAC}$. Thereafter, $\mathrm{K}^{+}, \mathrm{Na}^{+}$and $\mathrm{Ca}^{2+}$ were read from a flame photometer, while $\mathrm{Mg}^{2+}$ was read from atomic absorption spectrophotometer. The total soil exchangeable acidity $\left(\mathrm{Al}^{3+}+\mathrm{H}^{+}\right)$was measured by extracting with $1 \mathrm{~N} \mathrm{KCl}$, followed by titration with $0.1 \mathrm{M} \mathrm{NaOH}$ using Phenolphthalein indicator. Thereafter, cation exchange capacity (CEC) of the soil was determined as the sum of the total s exchangeable bases and the total exchangeable acidity $\left(\mathrm{Al}^{3+}+\mathrm{H}^{+}\right)$.

All the data generated were subjected to analysis of variance (ANOVA). Treatment means where significantly different from each other were separated by least significant difference (LSD) at 5\% level of probability.

\section{Results}

\subsection{Tuber Yield and Yield Related Components}

The sweet potato yield and yield related components response to the applied quantities (5 and $10 \mathrm{tha}^{-1}$ ) of PM, DPKC and PM + DPKC and the control between 2010 and 2011 are shown in Table 2. In any of the two years of the trial, plots that received either PM or DPKC or PM + DPKC, irrespective of the rate of application consistently gave a significantly $(\mathrm{P} \leq 0.05)$ higher total fresh and marketable tuber yields as well as fresh vine weights relative to un-amended (control) plots. Amongst the treated plots, the effect of PM and DPKC at similar rate of application on the yield parameters evaluated did not differ significantly, although the PM treated plots consistently out yielded those of DPKC in both years of the study. Yields obtained from the application of $10 \mathrm{tha}^{-1}$ of either PM or DPKC were significantly higher than those recorded from plots that had $5 \mathrm{t} \mathrm{ha}^{-1}$ of any of the two organic residues studied. 
Table 2. Effect of poultry manure (PM) and defatted palm kernel cake (DPKC) and their combinations on the tuber yield and yield related components $\left(\mathrm{t} \mathrm{ha}^{-1}\right)$ of sweet potato grown in a sandy loam ultisol of South-eastern, Nigeria

\begin{tabular}{|c|c|c|c|c|c|c|c|c|}
\hline \multirow[b]{2}{*}{ Treatment } & \multicolumn{4}{|c|}{2010} & \multicolumn{4}{|c|}{2011} \\
\hline & $\begin{array}{l}\text { Total tuber } \\
\text { yield }\end{array}$ & $\begin{array}{l}\text { Fresh vine } \\
\text { yield }\end{array}$ & $\begin{array}{l}\text { Marketable } \\
\text { tuber yield }\end{array}$ & $\begin{array}{l}\text { Unmarketable } \\
\text { tuber yield }\end{array}$ & $\begin{array}{l}\text { Total tuber } \\
\text { yield }\end{array}$ & $\begin{array}{l}\text { Fresh vine } \\
\text { yield }\end{array}$ & $\begin{array}{l}\text { Marketable } \\
\text { tuber yield }\end{array}$ & $\begin{array}{l}\text { Unmarketable } \\
\text { tuber yield }\end{array}$ \\
\hline $5 \mathrm{tha}^{-1} \mathrm{PM}$ & 14.5 & 20.25 & 11.64 & 2.86 & 13.8 & 19.08 & 10.32 & 3.48 \\
\hline $5 \mathrm{t} \mathrm{ha}^{-1}$ DPKC & 13.32 & 12.14 & 11.33 & 1.99 & 12.99 & 11.41 & 10.12 & 2.87 \\
\hline $10 \mathrm{t} \mathrm{ha}^{-1} \mathrm{PM}$ & 18.92 & 26.28 & 14.92 & 4 & 18.42 & 20.58 & 16.61 & 2.26 \\
\hline $10 \mathrm{t} \mathrm{ha}^{-1} \mathrm{DPKC}$ & 18.15 & 17.9 & 15.03 & 3.12 & 17.92 & 16.12 & 15.41 & 2.51 \\
\hline $5 \mathrm{tha}^{-1} \mathrm{PM}+\mathrm{DPKC}$ & 17.78 & 14.43 & 15.33 & 2.45 & 18.48 & 12.89 & 14.92 & 3.56 \\
\hline $10 \mathrm{tha}^{-1} \mathrm{PM}+\mathrm{DPKC}$ & 19.41 & 17.48 & 15.91 & 3.5 & 21.48 & 17.91 & 17.84 & 3.64 \\
\hline Control & 6.52 & 9.78 & 3.32 & 3.2 & 7.48 & 10.44 & 3.89 & 3.59 \\
\hline $\operatorname{LSD}(0.05)$ & 3.41 & 4.62 & 2.34 & 1.96 & 3.95 & 6.12 & 3.19 & 2.82 \\
\hline
\end{tabular}

Total fresh and marketable tubers and fresh vine yields obtained from the plots that received either PM or DPKC at the rate of 10 tha $^{-1}$ did not differ significantly from those recorded from plots that had PM + DPCKC at the rate of $5 \mathrm{t} \mathrm{ha}^{-1}$. Similarly, total fresh tuber yield (19.4 and $21.28 \mathrm{tha}^{-1}$ in 2010 and 2011, respectively) obtained from combined application of PM and DPKC (PM + DPCK) at the rate of $10 \mathrm{tha}^{-1}$ did not differ significantly from those (17.78 and $18.48 \mathrm{t} \mathrm{ha}^{-1}$ in 2010 and 2011 in that order) obtained from the plots that had similar treatment combination but at the rate of $5 \mathrm{tha}^{-1}$.

\subsection{Root:Vine Yield Ratio (R:V), Harvest and Commercial Harvest Indexes (HI and CHI)}

As shown in Table 3, the effect of the treatments on R:V, HI and CHI of sweet potato differed significantly from those of the control. In both years of the trial, plots that had DPKC alone or in combination with PM gave a significantly higher $\mathrm{R}: \mathrm{V}$ yield ratio compared to plots that had $\mathrm{PM}$ alone irrespective of the rate of application. The effect of the treatments on the crop commercial harvest index followed similar trend, except that they did not differ significantly at similar rate of applications.

Table 3. Effect of poultry manure, defatted palm kernel cake and their combinations on the Root/vine ratio (R:V) harvest index (HI) and commercial harvest Index (CHI) of sweet potato grown in a Sandy clay loam ultisol of South-eastern, Nigeria

\begin{tabular}{|c|c|c|c|c|c|c|}
\hline \multirow{2}{*}{ Treatment } & \multicolumn{3}{|c|}{2010} & \multicolumn{3}{|c|}{2011} \\
\hline & $\mathrm{R}: \mathrm{V}$ & $\mathrm{HI}$ & CHI & $\mathrm{R}: \mathrm{V}$ & $\mathrm{HI}$ & CHI \\
\hline $5 \mathrm{tha}^{-1} \mathrm{PM}$ & 0.72 & 0.42 & 0.8 & 0.72 & 0.42 & 0.75 \\
\hline $5 \mathrm{t} \mathrm{ha}^{-1}$ DPKC & 1.1 & 0.52 & 0.85 & 1.14 & 0.53 & 0.78 \\
\hline $10 \mathrm{tha}^{-1} \mathrm{PM}$ & 0.72 & 0.42 & 0.79 & 0.9 & 0.47 & 0.9 \\
\hline $10 \mathrm{tha}^{-1}$ DPKC & 1.81 & 0.46 & 0.83 & 1.14 & 0.49 & 0.86 \\
\hline $5 \mathrm{tha}^{-1} \mathrm{PM}+\mathrm{DPKC}$ & 1.23 & 0.55 & 0.86 & 1.43 & 0.59 & 0.81 \\
\hline $10 \mathrm{tha}^{-1} \mathrm{PM}+\mathrm{DPKC}$ & 1.11 & 0.52 & 0.86 & 1.2 & 0.55 & 0.83 \\
\hline Control & 0.67 & 0.04 & 0.51 & 0.72 & 0.42 & 0.52 \\
\hline $\operatorname{LSD}(0.05)$ & 0.25 & 0.04 & 0.07 & 0.31 & 0.03 & 0.05 \\
\hline
\end{tabular}

\subsection{Soil Org. C, Total $N$ and Available $P$}

Shown in Table 4, is the effect of the applied treatments on the soil organic $\mathrm{C}$, total $\mathrm{N}$ and available $\mathrm{P}$ after 2010 and 2011 crop harvest, respectively. Compared to the untreated plots, application of PM, DPKC and their combinations resulted to a significantly higher soil org. $\mathrm{C}$, total $\mathrm{N}$ and available $\mathrm{P}$ regardless of the rate of applications. In both years of the treatment application, the org. $\mathrm{C}$ content of the soil increased with increased rate of treatment application. Soil in plots that received PM + DPKC at the rate of $10 \mathrm{tha}^{-1}$ had a significantly higher values of org. $\mathrm{C}$ in $2010(1.31 \%)$ and 2011 (1.39\%) compared to those that had either PM or DPKC alone at that same rate of application. 
Table 4. Effect of poultry manure (PM) defatted palm kernel cake (DPKC) and their combination on the Org C, total $\mathrm{N}$ and available $\mathrm{P}$ content a sandy loam ultisol of South-eastern, Nigeria under sweet potato cultivation

\begin{tabular}{|c|c|c|c|c|c|c|c|c|}
\hline \multirow[b]{2}{*}{ Treatment } & \multicolumn{4}{|c|}{2010} & \multicolumn{4}{|c|}{2011} \\
\hline & Org. C & $\begin{array}{l}\text { Total N } \\
\text { /o)------- }\end{array}$ & $\begin{array}{l}\text { Av.P } \\
(\mathrm{mg} / \mathrm{kg})\end{array}$ & $\mathrm{C}: \mathrm{N}$ & Org. C & $\begin{array}{l}\text { Total N } \\
\text { (0)------ }\end{array}$ & $\begin{array}{l}\text { Av.P } \\
(\mathrm{mg} / \mathrm{kg})\end{array}$ & $\mathrm{C}: \mathrm{N}$ \\
\hline $5 \mathrm{tha}^{-1} \mathrm{PM}$ & 1.15 & 0.09 & 9.14 & 10.90 & 1.20 & 0.14 & 12.14 & 8.93 \\
\hline $5 \mathrm{tha}^{-1}$ DPKC & 1.12 & 0.07 & 8.16 & 12.44 & 1.26 & 0.11 & 10.61 & 10.82 \\
\hline $10 \mathrm{t} \mathrm{ha}^{-1} \mathrm{PM}$ & 1.21 & 0.13 & 14.44 & 9.92 & 1.28 & 0.15 & 16.82 & 9.20 \\
\hline $10 \mathrm{t} \mathrm{ha}^{-1}$ DPKC & 1.23 & 0.10 & 13.02 & 12.30 & 1.30 & 0.14 & 14.98 & 9.64 \\
\hline $5 \mathrm{tha}^{-1} \mathrm{PM}+\mathrm{DPKC}$ & 1.28 & 0.11 & 19.82 & 11.45 & 1.34 & 0.13 & 25.11 & 10.00 \\
\hline $10 \mathrm{tha}^{-1} \mathrm{PM}+\mathrm{DPKC}$ & 1.31 & 0.15 & 16.85 & 10.73 & 1.39 & 0.17 & 21.31 & 9.00 \\
\hline Control & 0.92 & 0.05 & 6.26 & 15.33 & 0.51 & 0.05 & 8.29 & 10.20 \\
\hline $\operatorname{LSD}(0.05)$ & 0.12 & 0.04 & 3.61 & 2.46 & 0.16 & 0.03 & 4.61 & NS \\
\hline
\end{tabular}

The total soil $\mathrm{N}$ ranged from $0.15-0.07 \%$ in plots that received PM + DPKC at the rates of 10 and $5 \mathrm{tha}^{-1}$, respectively, after 2010 crop harvest. At the end 2011 crop harvest, the soil total $\mathrm{N}$ appreciated slightly across the treatments with the highest value $(0.17 \%)$ being recorded from the plots that had $10 \mathrm{tha}^{-1}$ of PM + DPKC.

A consistently higher available soil $\mathrm{P}$ was recorded in the PM treated plots relative to the DPKC ones, irrespective of the rate of application. However, the value obtained from the combined application of PM and DPKC at the rate of $5 \mathrm{tha}^{-1}$ was significantly higher than those recorded in the plots that were treated with either PM or DPKC alone at the rate of $10 \mathrm{tha}^{-1}$.

\subsection{Soil pH, Exchangeable Bases and Acidity and CEC}

As indicated in Table 5, the treatment effect on the soil $\mathrm{pH}$, exchangeable bases and acidity and CEC differed significantly from those of the untreated. After 2010 crop harvest, a significantly higher soil $\mathrm{pH}$ values were recorded in plots that had PM + DPKC, irrespective of the rate of application compared to those treated with either PM or DPKC alone. Generally, applications of $10 \mathrm{t} \mathrm{ha}^{-1}$ of any of the two organic residues (PM or DPKC) either singly or in combination resulted in a higher $\mathrm{pH}$ values. The result in 2011 followed similar trend.

Table 5. Effect of poultry manure (PM) defatted palm kernel cake (DPKC) and their combination on the pH, Exchangeable bases and acidity and CEC of sandy loam ultisol of South-eastern, Nigeria under sweet potato cultivation

\begin{tabular}{|c|c|c|c|c|c|c|c|c|c|c|c|c|c|c|}
\hline \multirow{4}{*}{ Treatment } & \multicolumn{7}{|c|}{2010} & \multicolumn{7}{|c|}{2011} \\
\hline & \multicolumn{5}{|c|}{ Exchangeable bases } & \multicolumn{2}{|c|}{ Exchg. Acidity } & \multicolumn{5}{|c|}{ Exchangeable bases } & \multicolumn{2}{|c|}{ Exchg. Acidity } \\
\hline & & $\mathrm{Ca}^{2+}$ & $\mathrm{Mg}^{2+}$ & $\mathrm{K}^{+}$ & $\mathrm{Na}^{+}$ & $\mathrm{Al}^{3+}+\mathrm{H}^{+}$ & CEC & \multirow{2}{*}{$\begin{array}{l}\mathrm{pH} \\
\left(\mathrm{H}_{2} \mathrm{O}\right)\end{array}$} & $\mathrm{Ca}^{2+}$ & $\mathrm{Mg}^{2+}$ & $\mathrm{K}^{+}$ & $\mathrm{Na}^{+}$ & $\mathrm{Al}^{3+}+\mathrm{H}^{+}$ & CEC \\
\hline & $\left(\mathrm{H}_{2} \mathrm{O}\right)$ & \multicolumn{6}{|c|}{$-\left(\mathrm{Cmol} \mathrm{kg}^{-1}\right)$} & & \multicolumn{6}{|c|}{$-\left(\mathrm{Cmol} \mathrm{kg}^{-1}\right)----$} \\
\hline $5 \mathrm{tha}^{-1} \mathrm{PM}$ & 5.11 & 2.20 & 1.20 & 0.17 & 0.23 & 1.20 & 5.00 & 5.59 & 5.60 & 3.40 & 0.12 & 0.28 & 0.12 & 9.52 \\
\hline $5 \mathrm{tha}^{-1}$ DPKC & 5.26 & 1.70 & 0.93 & 0.21 & 0.20 & 1.09 & 4.13 & 5.21 & 3.92 & 2.60 & 0.14 & 0.21 & 0.16 & 7.03 \\
\hline $10 \mathrm{tha}^{-1} \mathrm{PM}$ & 5.16 & 3.70 & 1.70 & 0.21 & 0.25 & 1.28 & 7.14 & 5.72 & 7.26 & 4.10 & 0.19 & 0.36 & 0.24 & 12.15 \\
\hline $10 \mathrm{t} \mathrm{ha}^{-1}$ DPKC & 5.42 & 3.12 & 1.35 & 0.32 & 0.22 & 1.24 & 6.25 & 5.82 & 6.31 & 3.82 & 0.24 & 0.24 & 0.17 & 10.75 \\
\hline $5 \mathrm{tha}^{-1} \mathrm{PM}+\mathrm{DPKC}$ & 5.61 & 2.81 & 1.82 & 0.17 & 0.25 & 1.14 & 6.19 & 5.44 & 5.40 & 3.09 & 0.16 & 0.28 & 0.14 & 9.07 \\
\hline $10 \mathrm{tha}^{-1} \mathrm{PM}+\mathrm{DPKC}$ & 5.74 & 3.89 & 2.10 & 0.19 & 0.24 & 1.03 & 7.45 & 5.86 & 9.72 & 4.32 & 0.21 & 0.31 & 0.13 & 14.72 \\
\hline Control & 4.53 & 1.24 & 0.02 & 0.11 & 0.35 & 1.20 & 3.61 & 4.48 & 0.92 & 0.60 & 0.04 & 0.19 & 1.51 & 3.26 \\
\hline $\operatorname{LSD}(0.05)$ & 0.12 & 0.61 & 0.31 & 0.06 & NS & 0.04 & 2.16 & 1.04 & 2.01 & 0.92 & 0.02 & 0.09 & 0.04 & 5.61 \\
\hline
\end{tabular}

For the exchangeable bases, application of $10 \mathrm{tha}^{-1}$ of any of the organic materials resulted in a significantly higher $\mathrm{Ca}^{2+}$ and $\mathrm{Mg}^{2+}$ compared to $5 \mathrm{tha}^{-1}$ treatments. Plots that had PM + DPKC treatments gave higher values of $\mathrm{Ca}^{2+}$ and $\mathrm{Mg}^{2+}$ relative to those that had either of the two at the same rate of application. The concentration of $\mathrm{K}^{+}$in plots that were treated with DPKC alone at the rate of $10 \mathrm{tha}^{-1}$ in 2010 and $2011\left(0.32\right.$ and $0.24 \mathrm{Cmolkg}^{-1}$, respectively) were significantly higher than values recorded from plots that had PM alone or in combination with 
$\mathrm{DPKC}$ at the same rate .

The treatment effect on total exchangeable acidity differed significantly (Table 5). After 2010 crop harvest, the highest level of exchangeable acidity $\left(\mathrm{Al}^{3+}+\mathrm{H}^{+}\right)$was recorded from soils that were treated with $10 \mathrm{tha} \mathrm{of} \mathrm{PM}^{-1}$ This was followed by plots that received similar rate of DPKC. The result after 2011 crop harvest followed similar trend.

Generally, higher CEC values were obtained from plots that received $10 \mathrm{t} \mathrm{ha}^{-1}$ of any of the organic waste evaluated. The CEC of Soils that had either PM or DPKC at similar rates did not differ significantly in both years of the trial. However, there was a significant difference in the values obtained between plots that were treated with $5 \mathrm{tha}^{-1}$ and those of $10 \mathrm{tha}^{-1}$ of either PM or DPKC.

\section{Discussion}

In general, the annual application of PM or DPKC either singly or in combination, irrespective of the rate, significantly increased the total fresh tuber yield and other yield related components of sweet potato relative to the control (Table 2). Such yield increases in other crop like maize (Okore \& Akpobome, 2011) and cassava (Ogbonna et al., 2012) has been reported upon the application of DPKC either singly or in combination with mineral fertilizers in two separate locations in southern Nigeria. Similarly the yield range obtained with the application PM is within what was reported by Yeng et al. (2012) from different sites in Ghana using chicken manure. The yield increase recorded with the application of any of the organic waste (PM or DPKC or their combination) could be attributed to their nutrient content such as $\mathrm{N}$ and $\mathrm{K}$ as shown in Table 1. Several studies (Norman et al., 1984; Jian-weil et al., 2001; Njoku et al., 2001) have shown the critical importance of $\mathrm{N}$ and K ins the nutrition of sweet potato.

A non-significant difference in total fresh tuber and vein yields obtained from plots that received the same rate of either PM or DPKC could as well be ascribed to the variation in the $\mathrm{N}$ and $\mathrm{K}$ content of the two residues applied. While the $\mathrm{N}$ concentration in PM was higher than that of the DPKC, the $\mathrm{K}$ concentration in the DPKC was higher than that contained in the PM (Table 1). It could therefore be that these two nutrients $(\mathrm{N}$ and $\mathrm{K})$ play a kind of complementary role in yield performance of sweet potato based on their initial levels in the soil (Jacoby, 1965). The observed non significance difference in sweet potato yield performances between plots that had PM + DPKC at $5 \mathrm{t} \mathrm{ha}^{-1}$ and those that had either PM or DPKC at $10 \mathrm{tha}^{-1}$ may be due to improvement in the manure quality of the combined waste. Similar observation was made by Davari et al. (2012) following the combination of organic residues of different quality.

Significantly higher root:vine yield ratio, harvest and commercial harvest indexes (Table 3 ) obtained with the application of DPKC either singly or in combination with PM compared to PM application alone, demonstrate the relevance of $\mathrm{N}: \mathrm{K}$ ratios in fertilizers on sweet potato tuber weight and sizes and vine yield as reported by Norman et al. (1984) and Njoku et al. (2001). These workers in separate locations observed that fertilizers with lower $\mathrm{N}$ : $\mathrm{K}$ ratios promoted higher root:vine yield ratio and harvest index. Based on their nutrient composition (Table 1), the applied DPKC either singly or in combination with PM, had lower $\mathrm{N}: \mathrm{K}$ ratio compared to the singly applied PM.

A relatively significant improvement in the soil chemical characteristics (org. $\mathrm{C}$, available $\mathrm{P}$, exchangeable bases and $\mathrm{pH}$ ) recorded from the plots that had a mixture of PM and DPKC in both years of the trial (Tables 4 and 5) could be attributed to some modification in the quality of the mixed organic residue (Rajesh et al., 2003). It is in line with the observation of Okore et al. (2007) on a sandy clay loam soil of south-western Nigeria upon the combined application of organic waste of varying qualities.

\section{Conclusion}

The result of the study showed that yield performances of sweet potato that received similar rates of PM and DPKC did not differ significantly. However, the yields and its related components obtained from combined application of PM and DPKC (1:1 by weight) at the rate of $5 \mathrm{t} \mathrm{ha}^{-1}$ is favourably comparable to those obtained from the application of either PM or DPKC alone at the rate of $10 \mathrm{t} \mathrm{ha}^{-1}$. Similarly combined application of the organic residues resulted in an improved soil chemical characteristics. It could therefore be concluded that for improved sweet potato yield and sustained soil chemical properties improvement under a sandy loam ultisol, combined application of PM and DPKC is suitable.

\section{References}

Agboola, S. A. (1979). An Agricultural Atlas of Nigeria (pp. 29-52). Oxford University Press London.

Akoroda, M. (2009). Sweet potato in West Africa. In G. Loebenstein \& Thotapilly (Eds.), Sweet potato (pp. 
456-457). Spring Science Business Media, BV.

Chintala, R. D. E., Schumacher, T. E., Malo, D. D., \& Julson, J. L. (2013). Optimization of oxygen parameters for analysing carbon and nitrogen in bio char materials. Analytical Letters, 46(3), 532-538. http://dx.doi.org/10.1080/00032719.2012.721103

CRI (Crop Research Institute of Council for Scientific and Industrial Research Ghana). (2003). Annual Report for 2003. CSIR- CRI, Kumasi, Ghana.

Davaris, M., Sharma, S., \& Mirzakhani, M. (2012). Residual influence of organic materials, crop residues and biofertilizeron performance of succeeding Mung bean in organic rice based cropping system. Int. Jr. of Recycling Organic Waste in Agriculture, 1(14), 2-10. http://dx.doi.org/11886/2251-7715-1-14

Ekpete, D. M. (1972). Predicting response to Potassium for soils of Eastern Nigeria. Geoderma, 8, $177-189$. http://dx.doi.org/10.1016/0016-7061(72)90045-6

FIBL (African Organic Agriculture). (2011). Training Manual (Version 1.0, p. 50). In C. G. Weidmann \& L. Kilcher (Eds.). Research Institute of Agriculture, FIBL, Fric.

Hue, N. V., \& Silva, J. A. (1995). Organic soil amendment for sustainable organic sources of Nitrogen, Phosphorus and Potassium. In J. A. Silver \& Uchida (Eds.), Approach for Tropical and Sub Tropical Agriculture (pp. 133-144). College of Agric and Human Resources, Hawaii. Publ.

IITA (International Institute of Tropical Agriculture). (1982). Automated and semi-automated methods for soil and plant analysis. IITA Manual Series No. 7 (p. 33).

Jacoby, T. (196). Nutrition and Manuring of Tropical Root Crops (pp. 16-26). Verlagesellschalt and Furackerbau (publs).

Jian-weil, L., Fang, C., Yun-fan, W., \& Dong-bi, L. (2001). Sweet potato response to potassium. Better Crops International, 15(1), 10-12.

Maduakor, H. O. (1991). Efficient fertilizer use for increased crop production: The humid Nigeria experience. Fertilizer Research, 29, 65-79. http://dx.doi.org/10.1007/BF01048990

Njoku, J. C., Okpara, D. A., \& Asiegbu, J. E. (2001). Growth and yield response of sweet potato to inorganic nitrogen and potassium in tropical Utisol. Nig. Agric Jr., 32, 30-41. http://dx.doi.org/10.4314/naj.v3211-49367

Norman, M. J. T., Pearson, C. J., \& Searle, P. G. E. (1984). The Ecology of Tropical Food Crops (pp. 217-285). Cambridge University Press, Cambridge, London.

Ogbonna, P. E., Oluah, S. N., Jidere, C., \& Okafor, F. C. (2012). Effect of de-oiled palm kernel cake based fertilizer on sole maize and cassava crops. African Jr. of Biotech., 11(20), 4551-4557. http://dx.doi.org/10.5897/AJB11.2232

Okalebo, J. R., Gathua, K. W., \& Woomer, P. L. (1993). Laboratory Methods of Soil and Plant Analysis: A working Manual (p. 88). KARI (SSSEA) and TSBF, UNESCO-ROSTA (Publ.).

Okore, I. K., \& Akpobome, F. A. (2011). Effect of $\mathrm{N}$ fortified defatted rubber seed cake on nutrient content of a sandy loam ultisol of Mid-western Nigeria and maize yield. Chemtech Jr., 7, 157-164.

Okore, I. K., Tijani-Eniola, H., \& Aiyelari, O. P. (2007). Influence of organic manure and mineral fertilizer and their combination on maize, melon and cassava tuber yields and soil characteristics in South-western Nigeria. Jr. of Sustain. Agric. and Environ., 9(2), 136-145.

Rajesh, C., Reddy, K. S., Naidu, M. V. S., \& Ramavataram, N. (2003). Production and evaluation of compost and vermicompost from solid organic waste. Asian Journal of Microbiology, Biotechnology and Enviromental Science, 5, 301-311.

Titus, P. (2008). Crop Production Technical Guide: Sweet Potato (Ipomoea batata (L.) Lam.) (p. 11). Caribbean Agric, Res and Develpt. Inst. St. Vincent and Grenadine (Publ.).

Yeng, S. B., Agyarko, K., Dapah, H. K., Adomaka, W. J., \& Asare, E. (2012). Growth and yield of sweet potato (Ipomoea batata (L.) as influenced by integrated application of chemical manure and inorganic fertilizer. African Jr. of Agric Res., 7(39), 5387-539. http://dx.doi.org/10.5897/AJAR12.1s447 


\section{Copyrights}

Copyright for this article is retained by the author(s), with first publication rights granted to the journal.

This is an open-access article distributed under the terms and conditions of the Creative Commons Attribution license (http://creativecommons.org/licenses/by/3.0/). 